\title{
ケーソンに作用する地震時土圧に関する模型振動実験

\author{
MODEL VIBRATION TEST FOR THE SEISMIC EARTH PRESSURE \\ ACTING ON THE RIGID CAISSON FOUNDATION
}

\author{
風間基樹*・稲富隆昌** \\ By Motoki KAZAMA and Takamasa INATOMI
}

\begin{abstract}
The dynamic earth pressure acting on the rigid caisson foundation was studied by the model vibration tests. The model caisson used in the experiment enabled to measure the dynamic earth pressure. In order to account for the characteristics of the dynamic earth pressure influenced by the backfill ground vibration, frequency of an input sinusoidal wave was chosen very wide. The fundamental information of the dynamic earth pressure with frequency, the effect of the caisson mass on the dynamic earth pressure, its phase difference from the inertia force of the caisson and its distribution, were given in this experiment. And authors also regarded the dynamic earth pressure as a variation from the static one during vibration and compared experimental results with the MononobeOkabe formula.

Keywords : dynamic earth pressure, model vibration test, rigid caisson foundation, seismic stability
\end{abstract}

\section{1. まえがき}

地震時土圧は，古くから耐震工学，土質工学における 研究課題の 1 つであるが, 現在なお, 多くの課題を抱え ている11. 現在, 重力式構造物であるケーソン式護岸の 地震時土圧は, 物部・岡部が提案した地震時土圧式に よって算定している. 周知のとおり, 物部・岡部式は, 震度法をクーロン土圧に適用したものである。したがっ て, 物部・岡部式も, 地盤の塑性平衡状態を想定してい る. 物部・岡部式は, 擁壁などのように構造物の片側に のみ地盤がある場合の設計においては, 日本ばかりでな く，広く外国においても使用されている.

しかし, 物部・岡部式が, 地下タンクなどのように構 造物のほとんどが地中にある構造物, あるいは根入れセ ルのように構造物の前面にもある程度の地盤を有する構 造物の地震時土圧式として, 適切であるかどうかは検討 の余地がある.なぜなら, 構造物の前面に地盤がある場 合, 地震時に構造物が容易に滑動あるいは変形し, 構造 物前後の地盤が簡単に塑性平衡状態になるとは考えにく

* 正会員 運輸省港湾技術研究所構造部主任研究官 ( 㣙39 横須賀市長瀬 3-1-1)

** 正会員 工博 運輸省港湾技術研究所構造部構造振動研究 室長 (同上)
いからである。したがっでここような構造物の地震時 土圧としては, 地盤が塑性平衡状態になる以前の土圧を 考える必要がある. 現在, LNG 地下タンクの耐震設計 では, 物部・岡部の地震時主働土圧からクーロンの常時 主働土圧を差し引いた土王が地震時の土圧増分として用 いられている2.

地盤が，容易に塑性平衡状態に達しないと考えられる 根入れの深い構造物の地震時土圧を物部・岡部式によっ て計算することの是非のほかに, 静的な計算式である物 部・岡部式が, 動的現象である地震時土圧をどこまで説 明できるかを明らかにすることも必要である. 地震時に は, 地盤とともに，構造物も振動する．構造物に作用す る土圧は,地盤と構造物の相互作用の結果として生じる. その意味で, 壁高の高い護岸構造物や根入れの深い構造 物の地震時土压ほど，地盤と構造物の相互作用に大きく 影響される. 特に, 地震動の卓越振動数と構造物・地盤 系の固有振動数の関係が, 地震時土圧にとって重要であ ることは容易に想像できる3 ${ }^{3}$.しかし, このことについ ては，実験的に検証されていない。

物部・岡部式の妥当性を検討するため, 従来から数多 くの実験的研究が行われてきた. 初期の頃は, 振動箱の 内壁に作用する砂の土圧, あるいは支持条件の異なる壁 体に作用する土圧を計測しだ),5). また, 物部・岡部式 
の設定条件になるべく対応させるため, 壁体の固有振動 数から十分に離れた低い振動数で加振したり，あるいは 地盤が塑性平衡状態になるよう, 浱動中に壁体を移動, 傾斜させた実験も行われた ${ }^{6 / 8)}$. しかし, これら実験は, いずれも壁体自身の振動を考慮していない点で，実際の 現象と異なっていると考えられる。これら実験的研究に よると，土圧分布は深さ方向に三角形分布ではなく，壁 体上部の土圧が，大きな值を示していた．また，砂の相 対密度によって土圧の值が異なることも明らかにされ た.しかし, 振動実験で得られた主働土圧合力は, 物部 · 岡部式とおおむ稀うこともわかった。これは，振動実 験の条件が，前述のように物部・岡部式に対応するよう に設定されていたためと考えられる．しかし，常に，物 部・岡部が想定した条件で, 土圧が実物の構造物に作用 しているかどうかは疑問である，実際，実験で得られた 土圧分布は三角形ではなかったのであるから，地震時土 圧の発生メカニズムは, 物部・岡部式で考えた発生メカ ニズムと異なると考えた方が妥当であるう.

地中に埋設された剛体に作用する地震時土圧に関する 実験は，松澤らや岩楯らによって行われている ${ }^{9 / 10)}$. 岩 楯らの地中埋設剛体モデルの振動実験によると，

1）剛体底面が岩着したものとしないもので, 動的土 圧の分布形状が異なった。

2）入力加速度が $400 \mathrm{Gal}$ 程度までは，地盤は物部・ 岡部式が前提とするような塑性平衡状態になってお らず，土圧の值は同式による值よりもかなり小さ かった．また，入力加速度が $400 \mathrm{Gal}$ 以上になって も，地盤に土くさびは形成しなかった。 と報告している.

既往の研究成果等から，ケーソンの前面および背面の 地盤が地震時に容易に塑性平衡状態に達するか否か, ま
た基本的に静的な考察から導かれた物部・岡部式が実際 の動的土圧をどこまで説明できるかを明らかにすること が必要である，本研究は，これらのことを考えて模型振 動実験により，地震時土圧を検討したものである．既往 の実験と異なる点は，構造物に作用する土圧合力および 底面に作用する摩擦力や反力を計測できる模型ケーソン を使用し，ケーソン・地盤系の振動実験を行った点であ る.すなわち，本実験では，ケーソン・地盤の全体系が モデル化されており，ケーソンの慣性力と地震時土圧の 位相関係が議論できる.また, 既往の研究では, 主に“入 力加速度の大きさによって地震時土圧がどのように変化 するか”に注意が払われてきたが，本研究では，それに 加えて, 振動台の入力振動数を地盤の一次共振振動数の 2 倍程度まで与え, 地震時土圧の振動数依存性も検討し た.

\section{2. 実験方法}

\section{（1）模型ケーソン}

Fig. 1 に，模型ケーソンおよび，ケーソンに設置され た各変換器の位置を示す。ケーソンの大きさは，中詰め 砂を入れたケーソンが滑動および転倒に対して，十分な 安全率を確保するよう, 現行設計法によって決めた ${ }^{111}$.

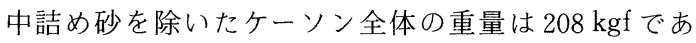
る. ケーソンの前面之背面, および底面には, 土圧合力 を計測するためのアルミニウム製受圧板を取り付けた。 各受圧板は，水平および上下方向の土圧合力を計測でき るように，3 個の 2 軸荷重計でケーソンに取り付けられ ている．また，各受圧板の中心線には，土圧計も取り付 けた．上下および水平方向で加速度を計測する点では， 番号の若い方が水平方向の計測点を表わしている. 以下 に示す実験結果は，Fig. 1 に示す変換器番号を用いて表
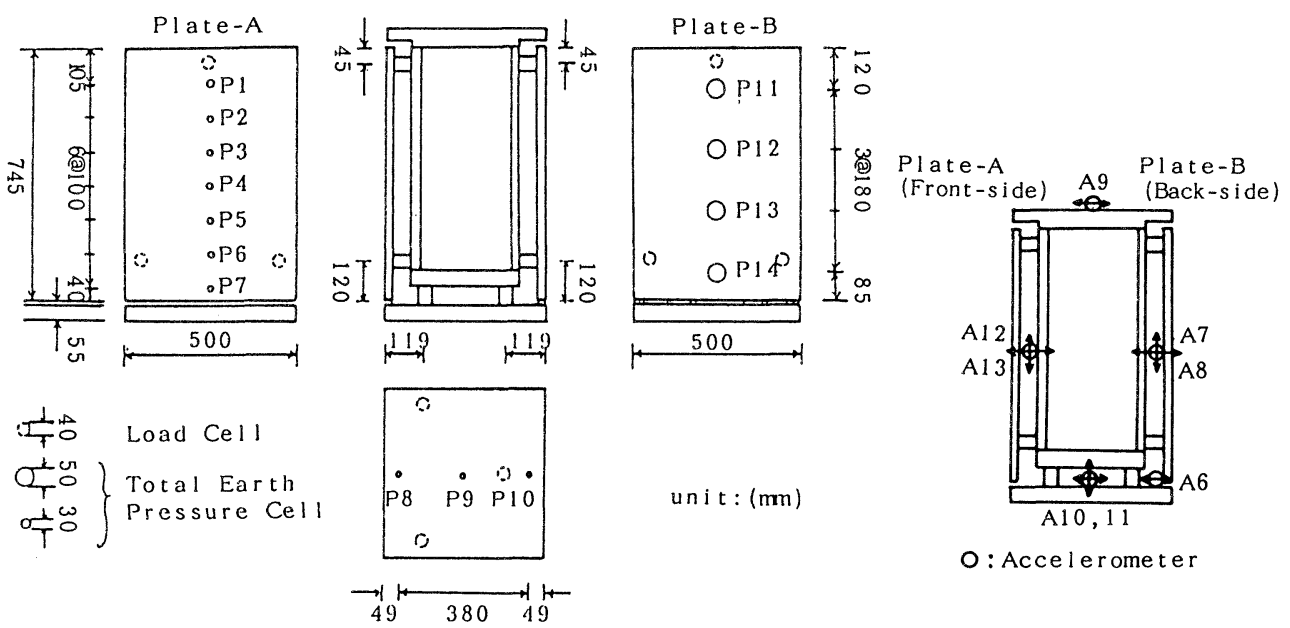

Fig. 1 Model caisson and the arrangement of transducers. 
示した.

\section{（2）受圧板の慣性力の除去方法}

受圧板は，板の曲げによる土圧計測の誤差を少なくす るため，十分に剛である必要がある。しかし，受圧板を 剛にすると，板厚を増すことになり，荷重計は受圧板の 慣性力も計測することになる。したがって，実際に作用 している土圧を求める場合には，計測された荷重計合力 から受圧板慣性力を除去する必要がある，たとえば，受 圧板 $\mathrm{A}$ の場合，実際に作用した土圧 $P(t)$ は，荷重計合 力 $\sum R_{A}(t)$ を用いて次式のように求められる.

$$
\left.\begin{array}{l}
\text { 水平方向 }: P_{A X}(t)=\sum R_{A X}(t)-m_{A} \ddot{X}_{A}(t) \\
\text { 上下方向 }: P_{A Y}(t)=\sum R_{A Y}(t)-m_{A} \ddot{Y}_{A}(t)
\end{array}\right\}
$$

ここで, $m_{A}, \ddot{X}_{A}, \ddot{Y}_{A}$ は, それぞれ受圧板 $\mathrm{A}$ の質量, 受 圧板重心の水平加速度と上下加速度である。また，添字 $X, Y$ は，水平および上下方向， $t$ は時間を表わす。こ の受圧板の慣性力の除去方法は，ケーソン背後に地盤が ないケーソンのみの予備振動実験を実施し，方法の適用 性を確認した。また，予備実験においては，受圧板を含 めたケーソン全体が剛体的な動きをしていることも同時 に確認した。

一般に振動実験では，土圧の波形はFig. 2 のようにな る。そこで，本文で使用する土圧に関する用語は以下の ように定義した．振動前に作用している土圧を“静的土 圧”, 静的土圧からの振動中の動的変動分 (片振幅) “動 的土压”と定義する. “地震時土圧” は，静的土圧に動 的土圧を重ね合わせたものとした．また，加振後に静的 土圧から残留した土圧を“残留土圧”とした。

\section{（3）実験条件}

実験ケースは，Fig. 3 に示す 4 ケースである．想定し た構造物は，ケーソン式護岸（ケース 1) と埋設剛体構 造物（ケース3）である。また，構造物の重量と動的応 答の関係を検討するため, ケーソンの中詰め砂を除去し た断面（ケース 2，4）の実験も実施した。図中のA 1 は 振動台， A 2 A 5 ，A15 は地盤の加速度計を示す.ケ一 ソンの加速度計の設置位置は，Fig. 1 のよおりである.

振動実験の入力波は $1 \mathrm{~Hz}$ から $50 \mathrm{~Hz}$ までの正弦波, 最大加速度は $20,50,100 \mathrm{Gal}$ の 3 種類である. 各振動 数とも, 応答が定常状態になるまで加振した。なお，ケ一 ス 1,3 の実験は，それぞれケース 2,4 の実験後に，背

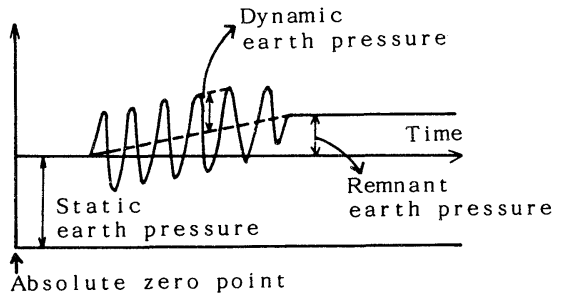

Fig. 2 Illustration of the earth pressure time history.
後地盤の沈下分の砂を補充するとともに，ケーソンに中 詰を投入して，再び加振したものである.

\section{（4）模型の作製方法}

模型は，以下の手順で作製した。まず，模型ケーソン とダミーケーソンは，互いに接触しないように砂地盤上 に立て込み，模型ケーソンとダミーケーソン，およびダ ミーケーソンと振動箱側壁の間は，蛇腹にしたビニール シートを張り，砂が漏れるのを防いだ。この状態を荷重 計と土圧計の初期状態とした。模型地盤は，ケーソンを 立て込んだ後, $20 \mathrm{~cm}$ 程度上方からまき出して作製した. 地盤作製後，振動数 $30 \mathrm{~Hz}$ ，加速度 $200 \mathrm{Gal}$ の振動を 30 秒間与え，実験時になるべく，残留土圧が発生しないよ うにした，模型地盤の物性を Table 1 に示す。また，夷 験終了後に, ケーソンを強制的に前傾させ，主働崩壊面 の角度を求め，クーロン士圧公式を用いて内部摩擦角を 推定した。その值は，35４5の間であった。なお，実 験に使用した砂は，秋田港の埋立地盤の砂である.

\section{3. 実験結果}

\section{（1）実験前の静的土圧}

Table 2 は，実験前の静的な土圧合力， 3 個の荷重計 Plane view

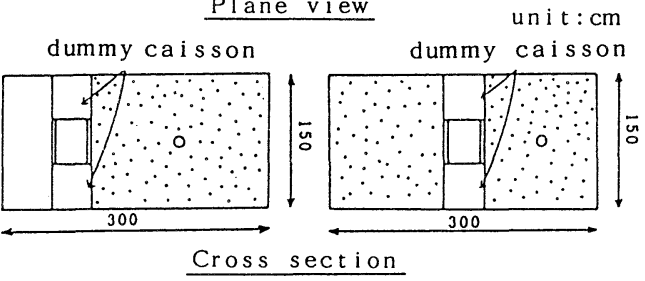

CASE-1

CASE- 3
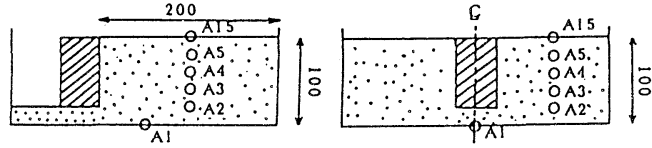

CASE- 2

CASE - 4

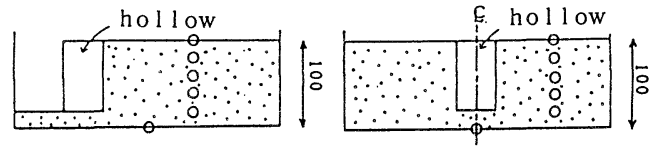

Fig. 3 The plane view and cross section of the model.

Table 1 Physical Properties of the Model Ground.

\begin{tabular}{|c|c|c|c:c|}
\hline \multicolumn{2}{|c|}{ CASE No. } & $\begin{array}{c}\text { Unit Weight } \\
\mathrm{t} / \mathrm{m}^{3}\left(9.8 \mathrm{kN} / \mathrm{m}^{3}\right)\end{array}$ & $\begin{array}{c}\text { relative Density } \\
(\%)\end{array}$ & $\begin{array}{c}\text { S-Wave Velocity } \\
(\mathrm{m} / \mathrm{s})\end{array}$ \\
\hline 1 & Back side & 1.561 & 53 & 113 \\
\hline 2 & Back side & 1.556 & 52 & 102 \\
\hline \multirow{2}{*}{3} & Front side & 1.589 & 62 & -- \\
\cline { 2 - 6 } & Back side & 1.597 & 64 & 161 \\
\hline \multirow{2}{*}{4} & Front side & 1.561 & 53 & - \\
\cline { 2 - 6 } & Back side & 1.567 & 55 & 158 \\
\hline
\end{tabular}


Table 2 Static Earth Pressure before Vibration.

\begin{tabular}{|l|l|c|c|c|}
\hline CASE No. & $\begin{array}{l}\text { Coefficient of } \\
\text { the static earth } \\
\text { pressure }\end{array}$ & $\begin{array}{l}\text { Height of the } \\
\text { action point }\end{array}$ & $\begin{array}{l}\text { Horizontal } \\
\text { earth pressure } \\
\text { kgf(9.8N) }\end{array}$ \\
\hline 1 & Back side & 0.359 & $0.475 \mathrm{H}$ & 76 \\
\hline 2 & Back side & 0.270 & $0.443 \mathrm{H}$ & 58 \\
\hline \multirow{2}{*}{3} & Front side & 0.544 & $0.321 \mathrm{H}$ & 120 \\
\cline { 2 - 5 } & Back side & 0.531 & $0.336 \mathrm{H}$ & 117 \\
\hline 4 & Front side & 0.518 & $0.355 \mathrm{H}$ & 114 \\
\hline & Back side & 0.518 & $0.344 \mathrm{H}$ & 112 \\
\hline
\end{tabular}

$\mathrm{H}:$ Caisson height

の力から求めた土圧合力の着力点高さ，また深さ方向の 土圧分布を三角形と仮定して求めた土圧係数を示したも のである．ケーソンの前面および背面に地盤があるケー ス 3,4 の静止土圧係数は, 約 0.5 , 一方, ケーソンの背 面のみに地盤があるケース 1,2 の静止土圧係数は, 約 0.3 であった．ケーソンの壁面摩擦角は，水平および上 下方向の荷重計合力から算定すると $5 \sim 10^{\circ}$ であった. また，土圧計で計測された土圧が，ケーソンの奥行き方 向に一様であると仮定して求めた土圧合力と荷重計で求 めた水平土圧合力を比較すると, 振動締め固め前で 0 $20 \mathrm{kgf}$, 締め固め後で 20 ～ $80 \mathrm{kgf}$ の差が認められた。こ れは, 数個の土圧計で土圧合力を推定することの困難さ， あるいは同一梁度の土圧は，奥行き方向に一様ではな かったこと，などによるものと考えられる，そこで，本 文では，土压計の值は定量的に取り扱うのではなく，深 さ方向の土圧分布を把握することに利用した。なお，荷 重計合力から，静的土圧之底面摩擦力のつり合いを検討 するとその誤差は, $1 \mathrm{kgf}$ 程度であった。

\section{（2）周辺地盤とケーソンの動的特性}

Fig. 4 は, ケース 1 の実験結果で，入力加速度に対す る背後地盤の加速度応答倍率を示したものである. 入力 加速度が小さいとき, 地盤の共振振動数は $28 \mathrm{~Hz}$ 付近に ある。また，入力加速度が大きくなると，地盤の応答に 非線形性が現われてくる。このような地盤の応答特性は 他のケースでも同じであった。ケーソンの応答特性は, 式 (2) を用いて，ケーソンの応答加速度 $(\ddot{A})$ をケーソ ンの並進水平加速度 $(\ddot{X})$, 並進上下加速度 $(\ddot{Y})$ および回 転加速度 $(\ddot{\theta})$ に分離して検討した ${ }^{12)}$ (Fig. 5 参照).

$$
\begin{aligned}
& \ddot{X}(t)=\left(\ddot{A}_{7}(t)+\ddot{A}_{12}(t)\right) / 2 \\
& \ddot{Y}(t)=\left(\ddot{A}_{8}(t)+\ddot{A}_{13}(t)\right) / 2 \\
& \ddot{\theta}(t)=\left(\ddot{A}_{8}(t)-\ddot{A}_{13}(t)\right) / B
\end{aligned}
$$

ここで, 添字の数字は Fig. 1 の加速度計番号の数字と対 応する. $B$ は加速度計 $\mathrm{A} 8$ と $\mathrm{A} 13$ の水平距離である.

Fig. 6 は， $50 \mathrm{Gal}$ 実験の結果で, 地表面（A15）の加 速度に対するケーソンの水平 $(\ddot{X})$ および回転 $(H \ddot{\theta} / 2)$ の 加速度応答倍率と, ケーソンの水平慣性力 $(M \ddot{X})$ を振動 数に対して示したものである。ここに， $H, M$ は，それ

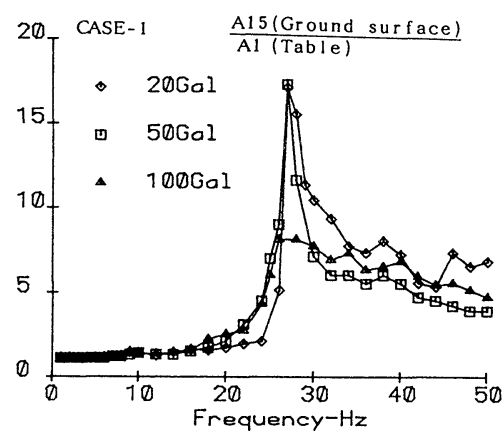

Fig. 4 Response curve of the back ground.

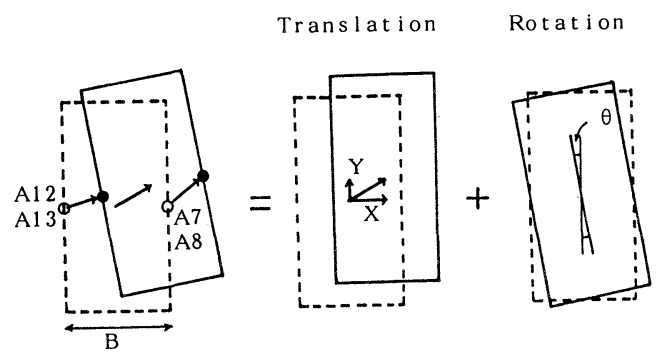

Fig. 5 Separation of the motion into translation and rotation.

ぞれケーソンの高さ，質量である．実験結果は，ケーソ ンの重量之動的応答の関係がわかるように，上段はケ一 ス 1 とケース 2 , 下段はケース 3 とケース 4 の結果を一 緒に示した．地表面の加速度に対するケーソンの加速度 応答倍率 (Fig. 6 a), d)）は, 入力振動数の増加ととも に小さくなり，地盤の一次固有振動数を越える高い振動 数領域では， 0.5 以下となる。一方，ケーソンの回転に 伴う天端の応答加速度 (Fig. 6 b), e) ) は, 地盤の一次 固有振動数付近で大きくなる。このような特性は, 周辺 地盤が深さ方向に位相差をもって振動するためで，幾何 学的動的相互作用として説明できる。次に，回転成分に ついて, 中詰のあるケースと中空のケースを比較すると， 中詰のあるケースでは地盤の一次固有振動数付近以外 (ケース 1 では, $24 \mathrm{~Hz}$ 付近，ケース 3 では $48 \mathrm{~Hz}$ 付近) にもピークがある．このピークは，ケーソンの質量の差 によって生じたと考えられるため，ケーソンの回転運動 の固有振動数亡考えられる.なお，回転成分に現われた ピーク振動数付近の並進水平成分の加速度応答倍率をみ ると，ケーソンの質量の大小で若干の差が認められる。 これは,並進運動と回転運動が連成しているためである.

ケーソンの水平慣性力 (Fig. $6 \mathrm{c}), \mathrm{f}))$ は，ケーソン の重量に比例するので，ケーソンの重量が小さいほど, 慣性力も小さくなる。しかし，ケーソンの重量の大きさ に関係なく慣性力は，周辺地盤およびケーソンの固有振 動数付近で大きくなる. 
a)

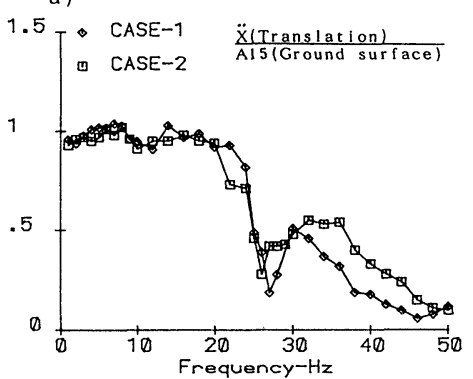

d)

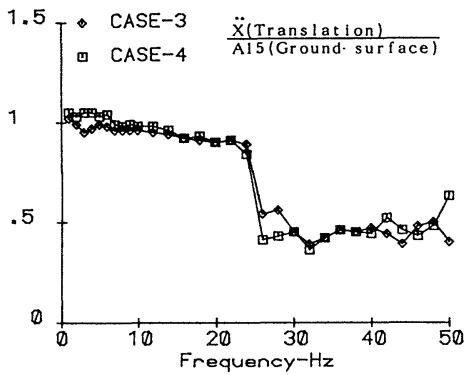

b)

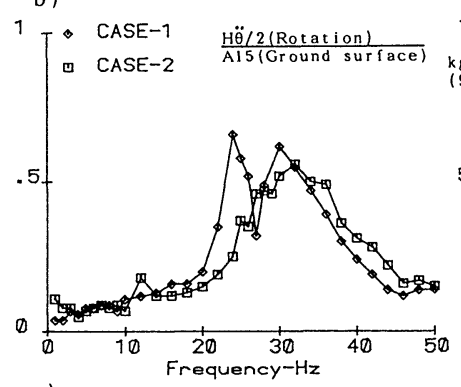

e)

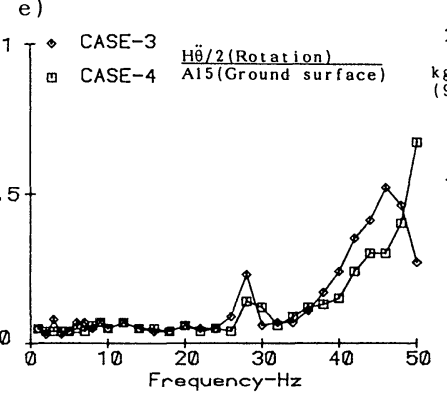

c)

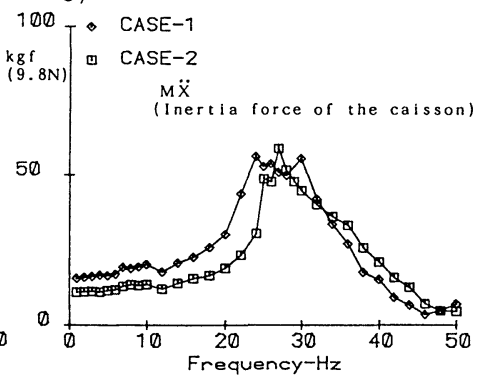

f)

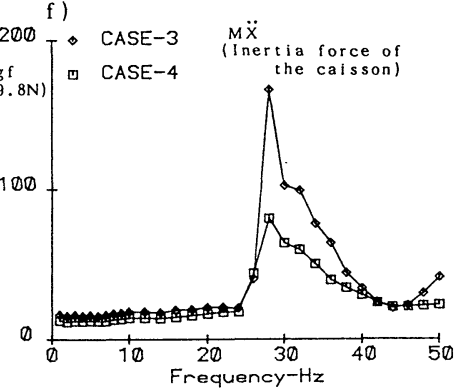

Fig. 6 Characteristics of the caisson response $(50 \mathrm{Gal})$.

a) CASE - 1

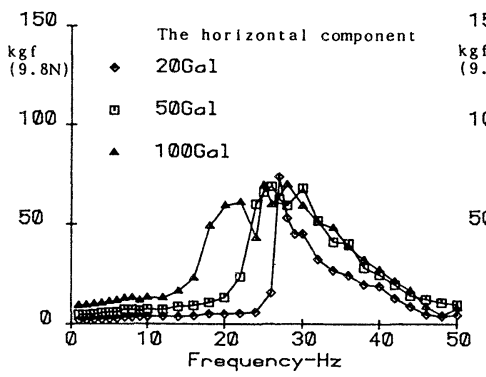

b) CASE - 3

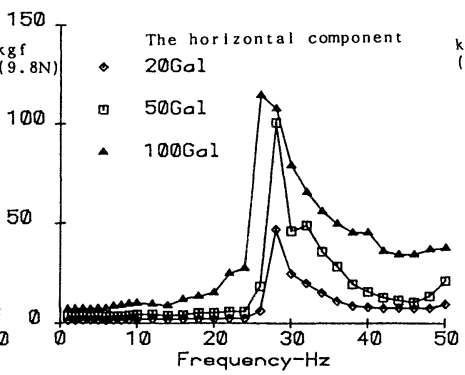

c) CASE- 1

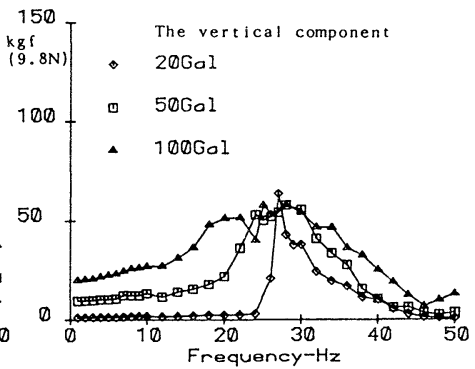

Fig.7 Dynamic earth pressure with frequency.

\section{（3）ケーソンに作用する動的土圧合力の特性}

Fig. 7 は, ケース 1,3 の実験結果で, 動的土圧合力を 入力振動数に対して示したものである. 背面にのみ地盤 があるケース 1 の水平土圧 (Fig. 7 a)) は, 入力振動数 が地盤およびケーソンの固有振動数に近づくと増大す る. また, 入力加速度レベルが大きいほど, 低振動数域 から大きくなっている.これは加速度レベルの増加に 伴って, 地盤のひずみが大きくなり, 地盤の剛性が低下 したためと考えられる. しかしながら, 地盤自身の材料 非線形性としては, Fig. 4 から加速度レベルが増加して も卓越振動数が顕著に低くなる傾向が現われていない. したがって，加速度レベルの増大に伴ってケース 1 の動 的土王合力が低振動数領域から大きくなるのは, 主に ケーソン周辺の地盤の剛性低下によって, ケーソンの固 有振動数が低下したためと考えられる. また，共振時の 土圧合力の大きさは, 入力加速度が大きくなっても, 大
きな変化がない.ケーソンの片側にのみ地盤が存在する ケース 1 の場合, ケーソンは共振時に容易に変形する. したがって, この共振時の動的土圧合力は, 壁体がある 程度変形したときの上限值と考えられる.

前面, 背面に地盤があるケース 3 の水平土圧 (Fig. 7 b)）も, 入力加速度の増大とともに大きくなる. しかし, 共振時の動的土圧合力の大きさは, ケース 1 の結果と異 なり, 入力加速度の増大とともに, 大きくなる. ケース 3 の場合, ケーソンは前面および背面の地盤によって拘 束されている. したがって, 共振時に変形がそれほど進 まず, 動的土圧は入力加速度に比例して大きくなったと 考えられる.

ケース 1 の上下方向の土圧 (Fig. 7c)) も, 水平方向 の場合と同様に, 地盤およびケーソンの固有振動数付近 で大きくなる. その大きさは, 水平方向の土圧合力と同 程度の值を示し, きわめて大きい. 現行の考え方で, 水 
平方向の土圧と上下方向の土圧の比を, 壁面摩擦角 $\delta$ で表わせば両者の比は, $\cos \delta / \sin \delta$ となるので, 実 験で得られたこの上下方向の動的土圧合力は，推定され た壁面摩擦角（ $7^{\circ} ）$ からは説明できない。これは，ケー ソンの回転に伴う地盤からの抵抗力と考えられる。

Fig. 8 は， $50 \mathrm{Gal}$ 実験の動的土圧合力をケース 1 と ケース 2 ，ケース 3 とケース 4 で比較したものである. 動的土圧は，ケーソン重量の大きい方（ケース1，ケー ス3）が，小さい（ケース 2，4）方より大きい.これは, 動的土圧がケーソンの慣性力の大きさによって変化する ことを示している。すすなわち，動的土圧は，地盤のみの 特性から考えるのではなく, 地盤・構造物の全体系の振 動現象としてとらえる必要がある.

\section{（4）慣性力と動的土圧合力の位相差について}

震度法に基づく重力式岸壁の現行設計法においては, 壁体の滑動安定性を検討する場合，地震時土圧は慣性力 と同一方向に作用させる ${ }^{11)}$ 。これは，壁体の慣性力と地 震時の土圧の増分が同位相であると考えているためで， 壁体に対しては安全側の考え方である.本研究では,ケー ソンの慣性力之動的土圧および底面摩擦力の位相差を, 次のように算出し，検討した.

いま, 角振動数 $\omega$ の正弦波加振で振動現象が定常状 態に達したとき，ケーソンに作用する慣性力，動的土圧 合力，底面摩擦力は次のように表わされる.

\section{慣性力 $: M \ddot{X} \cos \omega t$ \\ 動的土圧合力 : $P \cos \left(\omega t+\theta_{1}\right)$}
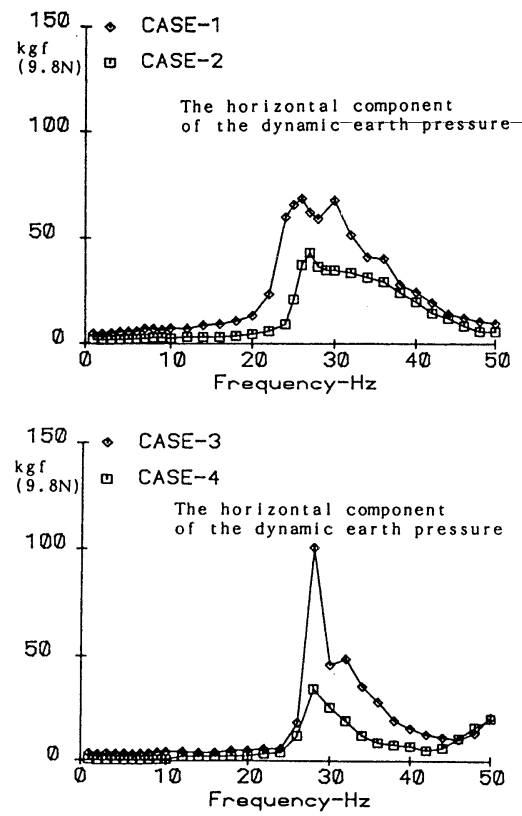

Fig. 8 Effect of the caisson mass on the dynamic earth pressure.
底面摩擦力 $: F \cos \left(\omega t+\theta_{2}\right)$

ここで， $\theta_{1}$ : 動的土圧合力の慣性力に対する位相差

$\theta_{2}:$ 底面摩擦力の慣性力に対する位相差

$M \ddot{X}:$ 慣性力の振幅

$P$ : 動的土圧合力の振幅

$F$ : 底面摩擦力の振幅

である.これらの力は振動時に常につり合っている.し たがって，式（3）で表わされる力のつり合い式

$M \ddot{X} \cos \omega t+P \cos \left(\omega t+\theta_{1}\right)$

$+F \cos \left(\omega t+\theta_{2}\right)=0$

は，時間 $t$ に対して恒等式である。すなわち，式 (4) が成り立つ。

$$
\begin{array}{r}
M \ddot{X}+P \cos \theta_{1}+F \cos \theta_{2}=0 \\
P \sin \theta_{1}+F \sin \theta_{2}=0
\end{array}
$$

実験では, これら外力の振幅が各振動数について求め られているので式 $(4)$ から， $\theta_{1}, \theta_{2}$ を求めることがで きる. Fig. 9 は, $50 \mathrm{Gal}$ 実験の $\theta_{1}, \theta_{2}$ を振動数ごとに示 したものである．慣性力に対する動的土圧合力の位相差 は，ほぼ全振動数にわたって $180^{\circ}$ に近い。一方，底面

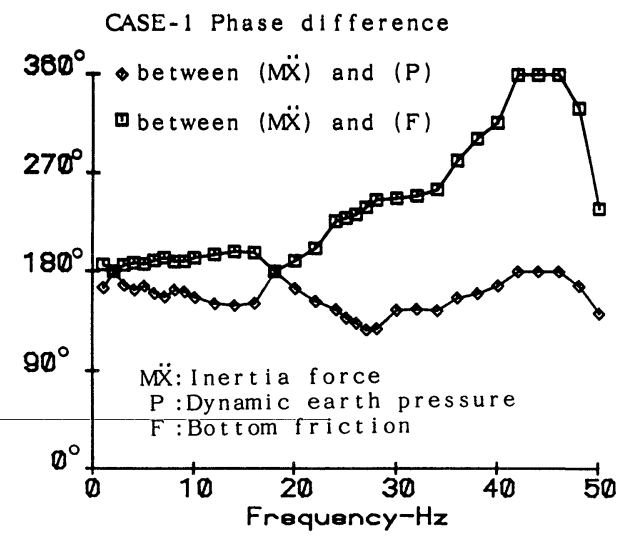

CASE - 3 Phase difference

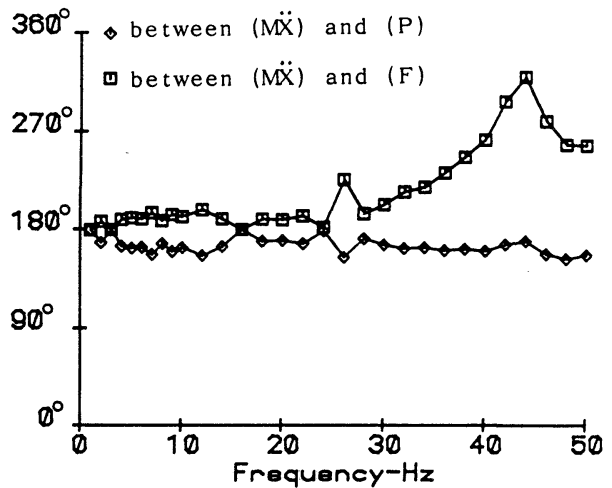

Fig. 9 Phase difference between inertia force of the caisson, dynamic earth pressure and bottom friction. 
摩擦力の慣性力に対する位相差は, $30 \mathrm{~Hz}$ 付近までは, 慣性力とほぼ $180^{\circ}$ の位相差をもつが，入力振動数が 35 $\mathrm{Hz}$ 以上になると, $270^{\circ} \sim 360^{\circ}$ となる. このような傾向 は $20 \mathrm{Gal}$ および $100 \mathrm{Gal}$ の実験でも同様であった.な お，ケース 3 の動的土圧合力は, ケーソン両側の動的土 圧合力を作用方向を考慮して合計したものとした。

Fig. 10 は, 底面摩擦力と慣性力の振幅の比率を振動 数 $30 \mathrm{~Hz}$ までについて示したものである. $30 \mathrm{~Hz}$ 付近ま では, 動的土圧合力も, 底面摩擦力も慣性力と逆位相で あるから，この図は，動的土圧と底面摩擦力の力の分担 を表わしているとみることもできる。図から，ケーソン の慣性力のうち, 6〜 割を底面摩擦力が動的に分担す ることがわかる。

\section{（5） ケーソンに作用する動的土圧の分布形状}

Fig. 11 は, 土圧計により計測された最大土圧を入力 加速度, 振動数ごとに示したものである. 実験によって 多少の差はあるが，動的土圧はケーソンの上端および下 端で大きくなる傾向がある。このような分布形は，ケ一

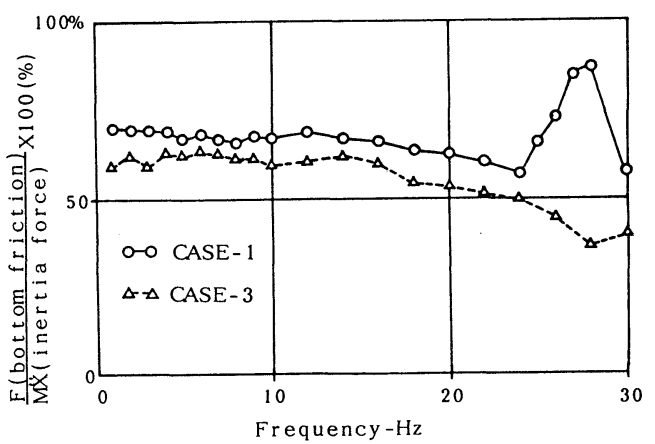

Fig. 10 Percentage of the bottom friction amplitude against the caisson inertia force amplitude.
ソンの回転運動に起因していると考えられる。

次に，耐震設計を考えた場合，加速度，土圧あるいは 土圧合力等の物理量が，時々刻々どのような関係にある かを知ることは重要である。そこで，これらの関係を同 時刻のデータを用いて検討した. Fig. 12 は, 入力振動 数が $10,20,30 \mathrm{~Hz}$ のときのケース 1 のケーソンの底面 摩擦力が最大となる時刻の結果である. 地盤とケーソン の変位，および両者間の相対変位は，加速度記録から求 めた，相対変位の符号は，縮む側を正とした．変位は, 入力波が正弦波であるため, 応答加速度 $\alpha$ と角振動数 $\omega$ を用いて，一 $-\alpha / \omega^{2}$ から求めた. 動的土压の深さ方向 の分布形状は, 三角形分布ではなく, おおむね, ケーソ ンと地盤の相対変位に対応している.しかし,場合によっ ては，明瞭に対応しないケースもある。この原因は，

(1) 入力加速度が増大すると, 地盤の挙動に非線形 性が現われる。

(2) ケーソンと周辺地盤間の相対変位を求める際, 周 辺地盤の変位として, ケーソンからどれくらい離れ た位置の変位を用いるかが明確でない.

(3) ケーソン側面の地盤反力係数, すなわち単位の相 対変位によって生じる力が，深さによって異なって いる.

ことなよ゙が考えられる.

\section{（6）物部・岡部式との比較}

a) 土圧合力について

前述の実験結果をみると，実際の地震時土压はどうも 物部・岡部の考えたものとは異なるように思われる.た とえば，動的土圧の分布形が明らかに三角形分布と異な ること，ケーソンの重量の大小によって動的土圧が異な ること，上下方向の動的土圧が水平方向と同じくらい大 きいことなどは，物部・岡部の考え方では説明できない
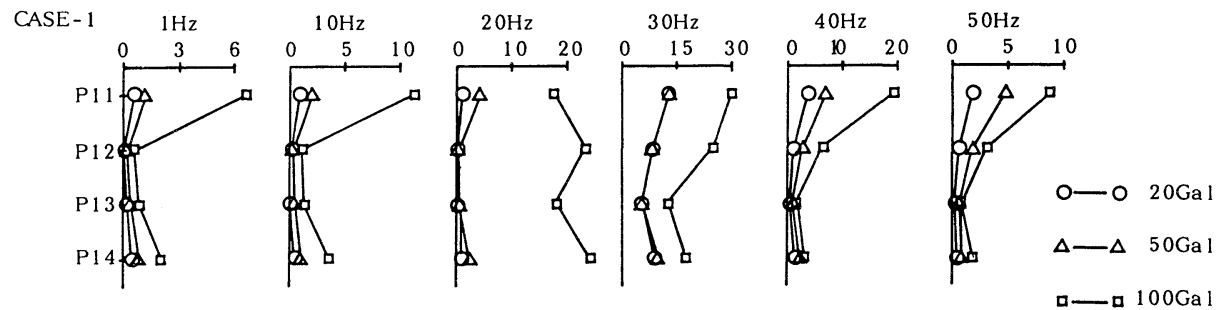

CASE- 3
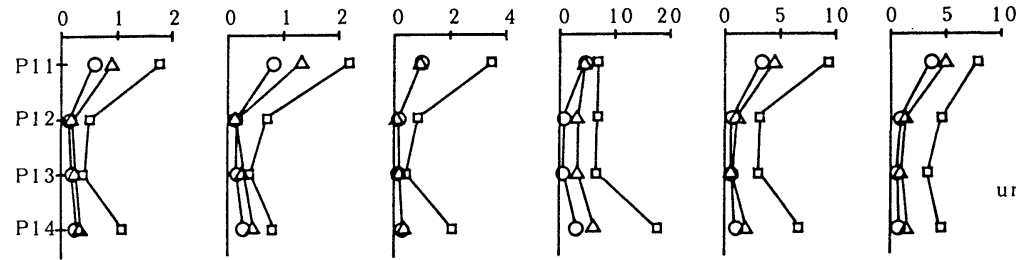

unit: $\mathrm{gf} / \mathrm{cm}^{2}$ $(0.98 \mathrm{kPa})$

Fig. 11 Distribution of the maximum dynamic earth pressure. 


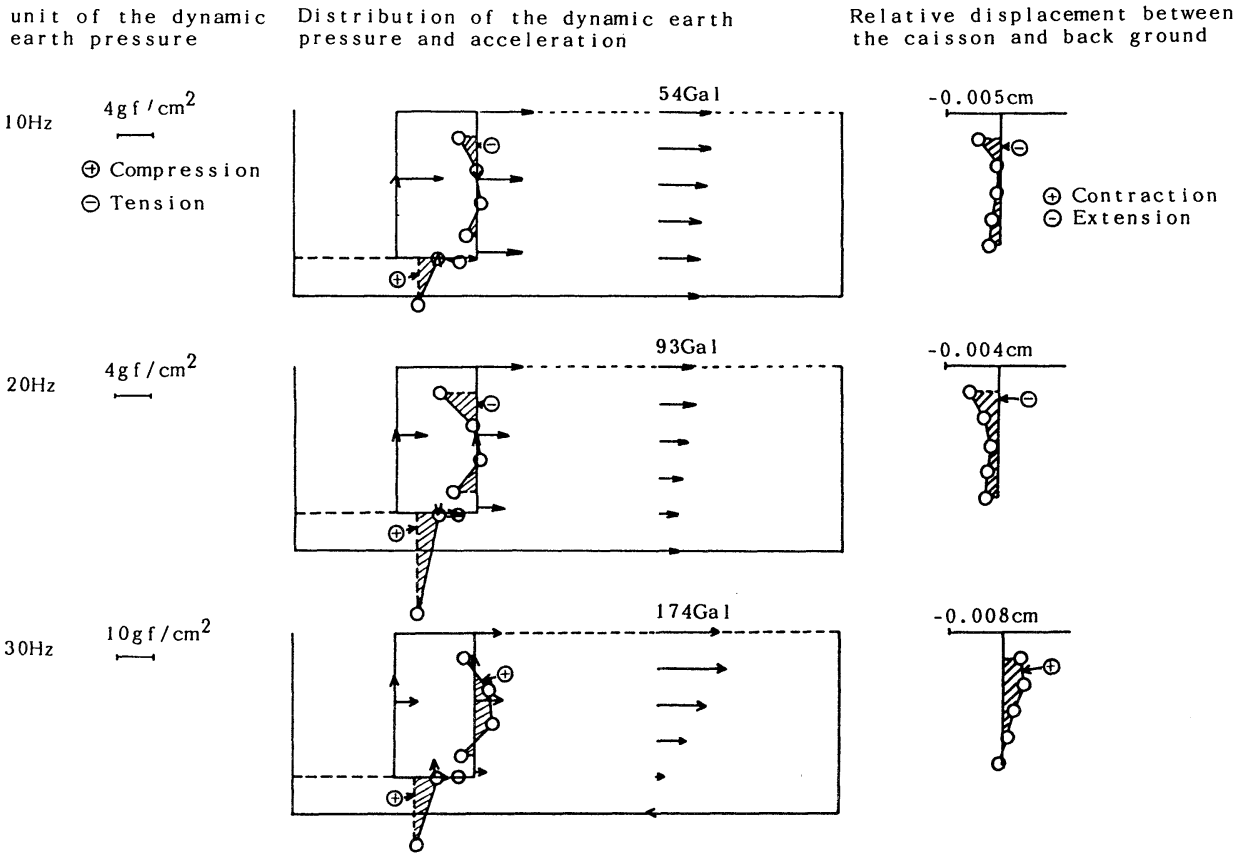

Fig.12 Relationship between the dynamic earth pressure distribution and relative displacement of the caisson and back ground (CASE-1, $50 \mathrm{Gal}$, at the time when the maximum bottom friction take place).

からである.

Fig. 13 は, ケーソンの変形に伴う土压の変化を模式 的に示したものである. ケーソンの変形が進むと, 静止 土圧 $P_{s}$ は, 常時主働土圧 $P_{a}(k=0.0)$ もしくは常時受働 土圧 $P_{p}(k=0.0)$ に向かって変化していく. 物部 ・ 岡部 式による地震時土圧合力は, 震度 $k$ が増加すると主働 土圧は増加し，受働土圧は減少する．このような土圧の 増減は，すべろうとする土塊に作用する慣性力とケーソ ンの変位の向きが同じと考えているためである. 実験結 果によると動的土圧とケーソンの慣性力は, ほぼ逆位相 であった。このように，地震時土圧に関する物部・岡部 式の考え方と実験結果は異なっていた。また，地震の規 模によっては，十分なひずみが発生せず，主働状態ある いは，受働状態に達しない場合も考えられる. しかし， 物部・岡部式は, 地盤に発生するひずみの大きさとは無 関係に主働あるいは，受働状態の土圧を与えてしまう。 本項では, 物部・岡部式と実験值を比較し, 同式の適用 性を検討する。

Fig. 14 は，100 Gal 実験の結果で，静的土圧合力，な らびに静的土圧に動的土圧を重㸚合わせた地震時土圧合 力を入力振動数に対して示したものである. ケース 3 の 結果は, 受圧板 Aに作用する土圧合力である. 地震時土 圧は, 入力振動数が地盤およびケーソンの固有振動数に 近づくにつれて, 主働側は静止土圧から小さくなり, 受 働側は大きくなる，実験による地震時土圧は，同一の入

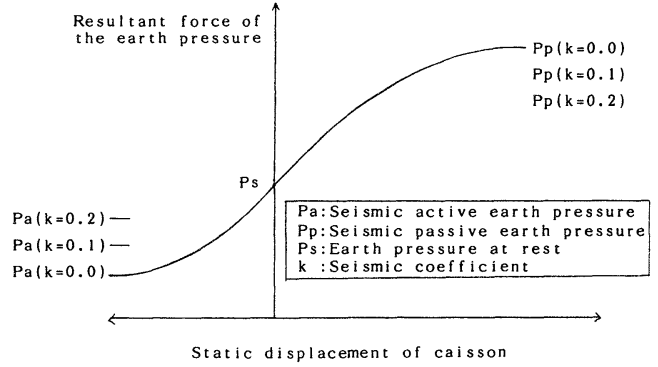

Fig. 13 Variation of the resultant force of earth pressure with static caisson displacement.

力加速度でも，このように振動数に大きく依存する。こ れは, 背後地盤の加速度応答に応じて動的土圧が変化し たと考えられる.Fig. 15 は，横軸にケーソンの中間深 さと同一レベルの背後地盤の応答加速度をとって, 実験 の地震時土圧合力を整理したものである．ここで，図の 横軸は加速度であるが，別の見方をすれば背後地盤に発 生したひずみの大きさとみなすことができる．物部・岡 部式で与えられる土圧は, 背後地盤に大きなひずみが発 生したときの極限の土圧と考えられるので，同図の両側 に同式による土圧合力を記入した。なお，受働土圧合力 は，図中に記入できなかったので図中の表に示した．地 震時土圧合力は，背後地盤の応答加速度の大きさに対応 して増減している．主働側については，ケーソンの前面 に地盤があるケース 3 の場合には，加速度が大きくなっ 
CASE- $1 \quad 100 \mathrm{Gal}$

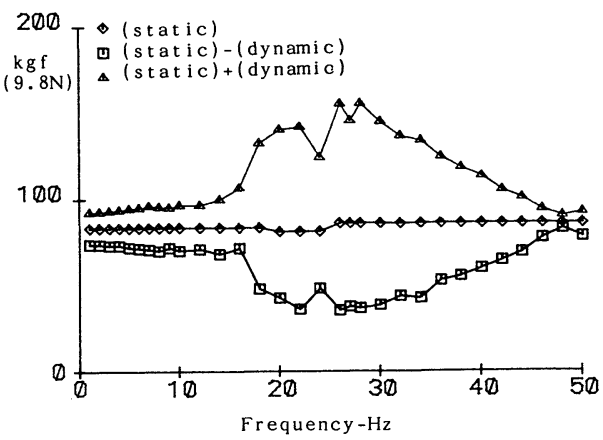

CASE- 3 A-side $100 \mathrm{Gal}$

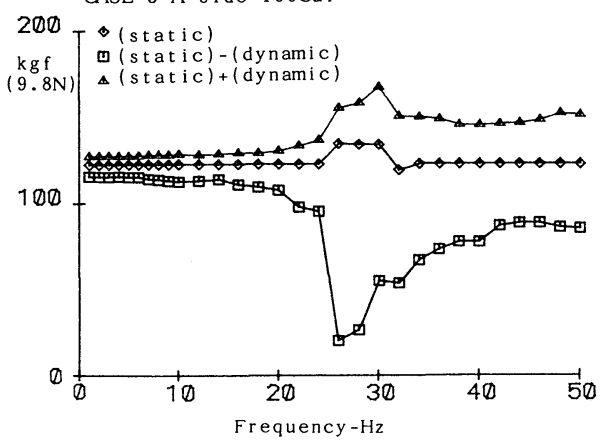

Fig. 14 Variation of the resultant force of seismic earth pressure with frequency.

てもなかなか主働状態の土圧合力に達していない.また， ケース 1 の主働側の実験值の中には物部・岡部式による 常時主働土圧合力より小さなものもある. 受働側につい ては,ケース 1,3 ともに実験值は同式による值より極 端に小さくなっている。したがって, $200 \mathrm{Gal}$ 以上の大 きな加速度が作用しても背後地盤は, 物部・岡部が想定 したような塑性平衡状態にはなっていなかったと考えら れる. また, 加速度が大きくなっても, 地震時の主働土 圧合力が大きくなったり, 地震時の受働土王が小さくな る現象はみられない。

b）動的土圧の分布形状について

地震時土圧から常時土圧を差し引いた土圧を動的土圧 と考えれば, 物部・岡部式で与えられる動的土圧は深さ 方向に三角形分布となる. 実験結果によると, 動的土圧 の分布形は, 明らかに三角形分布と異なっていた

(Fig. 11, 12 参照).

本文では，土圧分布については実験結果を示すのみに とどめた。土圧の分布形状は, 構造物の転倒モ一メント 等の算定に関係する. また, 構造物の内部応力度は単純 に最大土圧の分布のみで考えるのではなく，どのような 土圧分布のとき内部応力度が最大になるかなど別途の吟 味が必要である.

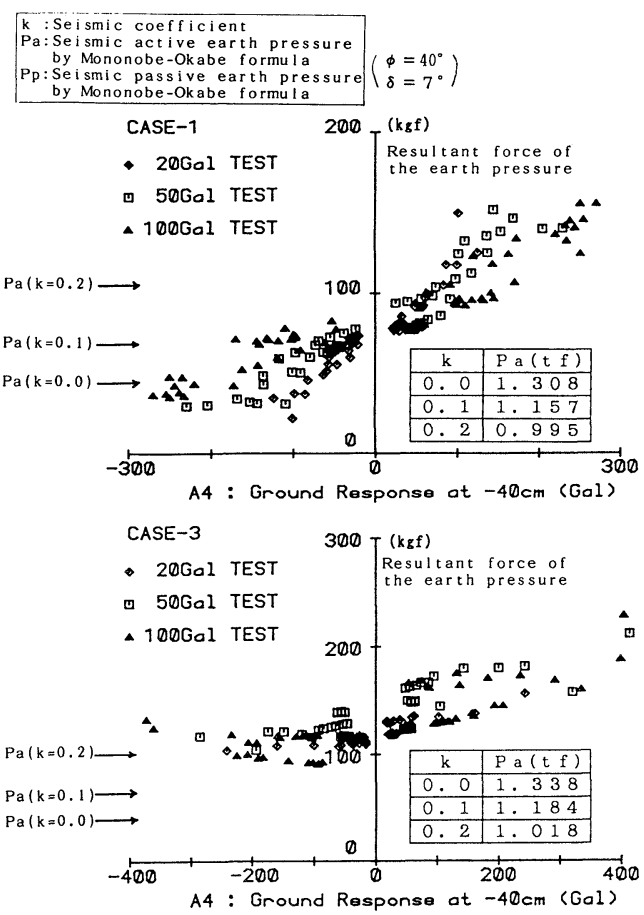

Fig. 15 Variation of the resultant force of seismic earth pressure with the ground response at $-40 \mathrm{~cm}$.

\section{4. 結 論}

護岸や上部構造物を伴わない地中ケーソンを想定した 模型振動実験から以下の結論を得た。

（1）剛なケーソンに作用する動的土圧は，周辺地盤 およびケーソンの固有振動数付近で増幅され，ケーソ ン・地盤系の振動特性の影響を強く受ける.すなわち, 動的土压は入力振動数に依存する.

（2）ケーソンに作用する動的土圧は，ケーソンの慣 性力の大きさによって異なる.したがって, 動的土圧は, ケーソン・地盤全体系の振動現象としてとらえる必要が ある。

（３）ケーソンの慣性力と動的土圧は, 逆位相の関係 にある.すなわち, 動的土王は慣性力に対して抵抗する 力となる. この結果は, ケーソン前面の地盤の有無にか かわらず，同じであった。

（4）実験結果を物部・岡部式の地震時土圧合力と比 較したところ, 一致しなかった。これは, 背後地盤の応 答加速度が大きくなっても，地盤が同式の想定したよう な塑性平衡状態に達しないためと考えられる.

（5）実験によると, 動的土圧は, 深さ方向に三角形 分布を示していない, また, 土圧分布は, ケーソンと地 盤間の相対変位の分布とよく対応していた。 
（6）本研究の結果を総合すると, 地震時土圧は地盤 の塑性平衡状態を想定して求めるより, 静的状態からの 振動時の変動分として考えた方が一般性があると考えら れる.

\section{5. あとがき}

ケーソンに作用する慣性力および動的土圧の基本的特 性を報告した. 今回の結果から, 地震時土圧は, 静的土 圧に動的土圧を重ねたものとして考えることができるこ とがわかった。しかし，今後の課題として以下のような ことが残されている.

（1）動的土圧は, 地震前の地盤状態によって影響を 受けると考えられる. したがって, 地震前の地盤状態を ビのように評価するかが重要である.

（2）護岸や岸壁は，水中に建設される. 水中での地 震時土圧を考えた場合, 振動による間隙水圧の上昇, あ るいは動水圧等の影響も考慮する必要があると考えられ る.

（３）実験結果によると，ケーソンに作用する慣性力 と動的土圧は逆位相であった。仮に，このことがあらゆ る場合に成立するとすれば，動的土圧はケーソンの慣性 力に抵抗するため, 合理的な地震時安定計算法が提案で きると考えられる，しかし，ケーソンの底面および側面 と接する地盤の剛性の大きさ，あるいはケーソン上の構 造物の存在によっては, ケーソンの慣性力と動的土圧の 位相関係が今回の実験結果と異なる可能性もある.した がって，どのような場合にケーソンの慣性力と動的土圧 が逆位相になるのかを明らかにする必要がある.

\section{参 考 文 献}

1) 大原資生 : 地震時土圧の現況之課題, 土木学会誌, pp. 2 $\sim 8,1979$ 年 5 月.

2）日本瓦斯協会：LNG 地下式貯槽指針，1979 年.

3）風間基樹・稲富隆昌：根入れのある剛体構造物の地震時 安定性に関する解析的研究, 港湾技術研究所報告, 第 25 巻, 第 3 号, pp. 71 124, 1986 年 9 月.

4）松尾春雄：擁壁に作用する地震時土圧の分布状態に関す る実験的研究, 土木学会誌, Vol. 27, No.2, pp. 83 106, 1941 年.

5）石井靖丸・林 聡・荒井秀夫・土田 肇：振動中にお ける乾燥砂の運動性状に関する研究（第三報～第五報）, 港湾技術研究所報告, 第 10 巻, 第 11 号, 1960 年.

6）市原松平：裏込め土砂の塑性平衡時における動的土圧に ついて, 第 2 回日本地震工学シンポジウム, pp. 121 126, 1966 年.

7) Ohara, S. : Experimental studies of seismic active and seismic passive earth pressure, 第 3 回日本地震工学シン ポジウム, pp. 137〜144, 1970 年.

8）市原松平・松沢 宏：耐震設計のための地震時土圧の特 性, 第 3 回日本地震工学シンポジウム, pp. 129 136, 1970 年.

9）松沢 宏・多賀直恒 - 今岡克也 - 加藤雅文：構造物根入 れ部に対する地震時水平支持機構に関する研究, 第 22 回 土質工学研究発表会, pp. 703 704, 1987 年.

10）岩楯尚広・当麻純一・国生剛治・栗原千鶴子・大友敬三 : 地震時土圧に関する実験的研究, 電力中央研究所報告, No. 384010,1985 年 12 月.

11）運輸省港湾局監修：港湾の施設の技術上の基準 - 同解説, 日本港湾協会, 1989 年.

12）風間基樹- 今村俊博 - 稲富隆昌 : 地震時の地中埋設剛体 構造物の回転運動に関する一考察, 第 40 回土木学会年次 学術講演会, pp. $677 \sim 678,1985$ 年 9 月.

(1989.5.16 • 受付) 